\title{
ANALISIS BIOEKONOMI SUMBERDAYA IKAN BAUNG DI PERAIRAN UMUM KABUPATEN KAMPAR PROVINSI RIAU
}

\author{
Ulfa Rizki Pradini ${ }^{1}$, Novia Dewi ${ }^{2}$ dan Fajar Restuhadi ${ }^{2}$ \\ ${ }^{1}$ Mahasiswa Pasca Sarjana Fakultas Pertanian Universitas Riau \\ ${ }^{2}$ Dosen Pasca Sarjana Fakultas Pertanian Universitas Riau \\ E-mail : ulfarizkipradini28@gmail.com
}

\begin{abstract}
ABSTRAK
Kabupaten Kampar memiliki potensi yang dapat dimanfaatkan yaitu salah satunya adalah kegiatan perikanan tangkap. Salah satu hasil tangkapan yang memiliki produksi tertinggi yaitu ikan baung. Kelestarian sumberdaya ikan baung akan terancam jika upaya pemanfaatan yang terus meningkat, dan tidak diupayakan langkah pengendalian. Tujuan dari penelitian adalah untuk menganalisis tingkat optimum pemanfaatan sumber daya perikanan tangkap ikan baung secara biologi dan ekonomi di perairan umum kabupaten Kampar. Penelitian ini dilaksanakan pada bulan Juli-Agustus 2020. Hasil penelitian menunjukkan produksi optimal $\left(\mathrm{C}_{\text {opt }}\right)$ pada MSY sebesar 61.510 ton/tahun dengan effort optimum $\left(\mathrm{E}_{\mathrm{opt}}\right) 116.764$ unit/tahun dan rente ekonomi sebesar Rp2.353.594.693.969. Produksi optimal $\left(\mathrm{C}_{\mathrm{opt}}\right)$ pada MEY sebesar 61.489 ton/tahun dengan effort optimum $\left(\mathrm{E}_{\mathrm{opt}}\right) 114.567$ unit/tahun dan rente ekonomi sebesar Rp2.354.461.065.478.
\end{abstract}

Kata kunci : Model surplus produksi, tingkat pemanfaatan optimum, ikan baung.

\section{ABSTRACT}

Kampar Regency has potential that can be exploited, one of which is capture fisheries activities. One of the catches that has the highest production is Baung Fish. The sustainability of fish resources will be threatened if the use of efforts continues to increase, if no control measures are taken. The purpose of this study was to analyze the optimum level of biological and economic utilization of baung fishery resources in the public waters of Kampar district. This research was conducted in July-August 2020. The results showed that the optimal production $\left(C_{\text {opt }}\right)$ at MSY was 61,510 ton / year with optimum effort $\left(E_{\text {opt }}\right)$ of 116,764 unit / year and economic rent of IDR 2,353,594,693,969. Optimal production $\left(C_{\text {opt }}\right)$ in $M E Y$ is 61,489 ton / year with optimum effort $\left(E_{\text {opt }}\right)$ of 114.567 unit / year and economic rent of IDR 2,354,461,065,478.

Key words : Surplus production model, optimum utilization rate, baung fishery.

\section{PENDAHULUAN}

Sungai Kampar merupakan salah satu sungai yang terdapat di kabupaten Kampar dengan panjang 413,5 km. Sungai Kampar merupakan tempat usaha perikanan tangkap yang produktif di Kabupaten Kampar. Sungai Kampar memiliki sumber daya ikan dengan keanekaragaman yang tinggi. Salah satu komoditas unggulan lokal Sungai
Kampar adalah ikan baung. Kegiatan usaha perikanan tangkap di Kabupaten Kampar masih dominan pada usaha perikanan tangkap tradisional dengan armada penangkapan < 5 GT dan menggunakan alat tangkap jaring insang.

Sumber daya perikanan termasuk sumber daya yang dapat diperbaharui akan tetapi jika penangkapan terus 
dilakukan tanpa adanya pembatasan maka akan menyebabkan terkurasnya sumberdaya tersebut

Adanya kekhawatiran terkait menurunnya daya dukung lingkungan terhadap ketersediaan sumber daya ikan membuat munculnya konsep perikanan yang berkelanjutan. Pada umumnya, sumber daya perikanan bersifat open access yang berarti setiap orang dapat memanfaatkannya sehingga tidak ada batasan terkait dengan besarnya upaya penangkapan terhadap sumber daya ikan yang boleh ditangkap (Usman, 2016).

Suman (2004) menyatakan bahwa penambahan jumlah upaya penangkapan pada batas tertentu akan menyebabkan peningkatan produksi, tetapi jika terus terjadi penambahan upaya, maka suatu saat akan terjadi penurunan stok. Dengan kondisi tersebut, jika kondisi pola pemanfaatan sumber daya ikan baung yang ada saat ini tetap berlangsung, maka ke depannya sumber daya ikan baung di perairan sungai Kampar terancam punah.

Untuk mencegah terjadinya pemanfaatan sumber daya ikan baung secara berlebihan, maka perlu dilakukannya sebuah penelitian terhadap pemanfaatan sumber daya tersebut.. Salah satu pendekatan analisis yang digunakan dalam penelitian ini untuk memperoleh pemanfaatan yang optimal dan berkelanjutan yaitu dengan menggunakan pendekatan bioekonomi. Pendekatan bioekonomi yang digunakan pada penelitian ini yaitu Model Gordon Schaefer dengan Model Estimasi Parameter Schnute.

Tujuan dari penelitian ini adalah untuk menganalisis tingkat optimum pemanfaatan sumber daya perikanan tangkap ikan baung secara biologi dan ekonomi di perairan umum kabupaten Kampar.

\section{METODE PENELITIAN}

Penelitian ini dilaksanakan di Kabupaten Kampar Provinsi Riau pada bulan Juli-Agustus 2020 dengan lokasi pengambilan sampel di Tempat Pendaratan Ikan (TPI) Teratak Buluh. Metode yang digunakan yaitu metode survey.

Data yang digunakan yaitu data primer dan sekunder hasil tangkapan ikan baung di kabupaten Kampar. Data produksi dan upaya tangkap diperoleh dari Dinas Perikanan Kabupaten Kampar time series 2009 - 2020.

Pengambilan sampel dilakukan dengan metode purposive sampling atau pemilihan responden dengan sengaja berdasarkan kriteria seperti: responden adalah nelayan jaring insang kurang < 5 GT yang melakukan penangkapan terhadap sumber daya ikan baung dan beroperasi di perairan sungai Kampar.

\section{Analisis Data}

Model penduga yang dianalisis menggunakan 5 model, namun model yang dianggap baik yaitu : Schnute. Model tersebut dihitung nilai $\mathrm{C}_{\mathrm{MSY}}$, upaya tangkap optimum ( $\mathrm{E}_{\mathrm{MSY}}$ ), tingkat pemanfaatan, dan tingkat pengusahaan sumberdaya ikan baung.

\section{Model Schaefer}

Model produksi surplus pertama kali dikembangkan oleh Schaefer, yang bentuk awalnya sama dengan model pertumbuhan logistik. Model tersebut ialah sebagai berikut:

$$
\begin{aligned}
& \frac{d B}{d t}=\mathrm{G}(\mathrm{Bt})=\mathrm{r} \mathrm{Bt}\left(1-\frac{B}{K}\right) \\
& \text { Persamaan }
\end{aligned}
$$

belum memperhitungkan pengaruh penangkapan, sehingga Schaefer menuliskan kembali menjadi :

$$
\frac{d B}{d t}=\mathrm{r} \mathrm{Bt}\left(1-\frac{B}{K}\right)-\mathrm{Ct}
$$

dengan $\mathrm{K}$ ialah daya dukung lingkungan perairan, dan $\mathrm{Ct}$ ialah 
tangkapan yang dapat ditulis sebagai :

$$
\mathrm{Ct}=\mathrm{q} \text { Et Bt }
$$

dengan $\mathrm{q}$ sebagai koefisien ketertangkapan (catchability), dan Et menunjukkan upaya tangkap. Persamaan ini dapat ini ditulis menjadi: $\frac{C_{t}}{E_{t}}=q B_{t}=\mathrm{CPUE}$

Berdasarkan persamaan 2, tangkapan optimum dapat dihitung pada saat $\frac{\partial B_{t}}{\partial_{t}}=0$ atau disebut juga penyelesaian pada titik keseimbangan yang berbentuk :

$$
r B_{t}\left(1-\frac{B_{t}}{k}\right)-C_{t}=0
$$

atau

$$
C_{t}=r B_{t}\left(1-\frac{B_{t}}{k}\right)=q F_{t} B_{t}
$$

Berdasarkan persamaan 3 dan 6 nilai $B_{t}$ dapat diperoleh sebagai berikut

$$
B_{t}=K\left(1-\frac{q E_{t}}{r}\right)
$$

Sehingga persamaan 6 diperoleh :

$$
C_{t}=q f_{t} K\left(1-\frac{q E_{t}}{r}\right)
$$

Persamaan 11 disederhanakan lagi oleh Schaefer menjadi :

$\frac{c_{t}}{f_{t}}=q K-\frac{q^{2} k}{r} f_{t}$

$$
=\mathrm{a}+b f_{t} \text { atau } c_{t}=a f_{t}+b f_{t}^{2}(9)
$$

Sedangkan $\mathrm{a}=\mathrm{qK}$ dan $\mathrm{b}$ $=-q^{2} K / r$. Hubungan linier ini digunakan secara luas untuk menghitung MSY melalui penentuan turunan pertama $C_{t}$ terhadap $F_{t}$, yaitu dalam rangka menentukan solusi optimal baik untuk usaha maupun tangkapan. Turunan pertama turunan pertama dari $C_{t}$ terhadap $F_{t}$, yaitu :

$$
\frac{\partial B_{t}}{\partial_{t}}=a-2 b f_{t}
$$

Hasil tangkapan $C_{t}$ akan mencapai maksimum apabila $\frac{\partial C_{t}}{\partial f t}=0$ sehingga diperoleh dugaan $f_{M S Y}$ dan $C_{M S Y}$ dan masing-masing :

$$
\mathrm{f}_{\mathrm{MSY}}=\frac{a}{2 b}=\frac{r}{2 q}
$$

$$
\mathrm{C}_{\mathrm{MSY}}=\frac{a^{2}}{4 b}=\frac{r K}{4}
$$

\section{Model Schnute (1977)}

Model ini dikembangkan oleh Schnute tahun 1977 dengan metode regresi relatif. Schnute memodifikasi persamaan model Schaefer dengan menggunakan prosedur integrasi.

$$
\frac{d x}{x}=\left(r-\frac{r}{K} x-q E\right) d t
$$

Integrasi persamaan di atas melalui langkah one - years time, dapat diperoleh persamaan :

$$
\begin{aligned}
\ln \left(x_{t+1}\right)-\ln \left(x_{t}\right) & =r-\frac{r}{K} \bar{x}-q \bar{E}(14) \\
\operatorname{dimana}: & \bar{x}=\int x d t \\
\mathrm{E} & =\int E d t
\end{aligned}
$$

Sehingga didapat :

$\ln \left(\frac{U_{t+1}}{U_{t}}\right)=r-\frac{r}{K} \bar{E}-q \bar{E}$

Dimana :

(CPUE)

$\bar{U}=$ rata-rata catch per unit effort (effort)

$$
\bar{E}=\text { rata rata upaya tangkap }
$$

Dengan menggunakan rata-rata geometrik, persamaan di atas melalui modifikasi aljabar dapat ditulis sebagai berikut

$$
\ln \left(\frac{U_{t+1}}{U_{t}}\right)=\mathrm{r}-\frac{r}{q K}\left(\frac{U_{t}+U_{t+1}}{2}\right)-q\left(\frac{E_{t}+E_{t+1}}{2}\right)
$$

Persamaan ini menunjukkan bahwa model surplus produksi Schnute adalah non-linear, lag dan reciprocal. Persamaan di atas adalah persamaan regresi yang dapat diestimasi menggunakan Regresi, dimana :

$$
\begin{aligned}
Y_{t} & =\ln \left(\frac{U_{t+1}}{U_{t}}\right) \\
X_{1 t} & =\frac{U_{t}+U_{t+1}}{2} \\
X_{2 t} & =\frac{E_{t}+E_{t+1}}{2}
\end{aligned}
$$

\section{HASIL DAN PEMBAHASAN}

Hasil produksi ikan baung di perairan Sungai Kampar selama 12 
tahun berfluktuatif. Data produksi ikan baung selama tahun 2012-2020, disajikan pada Tabel 1 .

CPUE menggambarkan tingkatan nilai produktivitas alat tangkap yang digunakan. Apabila CPUE mengalami penurunan artinya hasil tangkapan rendah, namun upaya penangkapan relatif tinggi. (Arief, 2016). Pada Tabel 1, CPUE ikan baung mengalami fluktuasi.

Tabel 1. Perkembangan CPUE Ikan Baung di Kabupaten Kampar Tahun 2009-2020

\begin{tabular}{cccc}
\hline Tahun & Produksi (ton) & Upaya (Unit) & CPUE (ton/unit) \\
\hline 2009 & 431 & 6.000 & 0,071833 \\
2010 & 530 & 6.198 & 0,085511 \\
2011 & 690 & 6.220 & 0,110932 \\
2012 & 480 & 6.480 & 0,074074 \\
2013 & 412 & 6.500 & 0,063385 \\
2014 & 580 & 7.780 & 0,07455 \\
2015 & 400 & 7.810 & 0,051216 \\
2016 & 364 & 7.900 & 0,046076 \\
2017 & 560,8 & 7.920 & 0,070808 \\
2018 & 554,69 & 8.001 & 0,069328 \\
2019 & 548,58 & 8.420 & 0,065152 \\
2020 & 620,75 & 8.447 & 0,073488 \\
\hline Rata-rata & & $\mathbf{0 , 0 7 1 3 6}$
\end{tabular}

Berdasarkan Tabel 1, nilai CPUE tertinggi pada tahun 2011 yaitu 0,110932 ton/unit, dan nilai CPUE terendah pada tahun 2016 sebesar 0,046076 ton/unit. Hal ini berarti alat tangkap gill net merupakan alat tangkap yang paling produktif pada tahun 2011. Oleh karena itu, besaran CPUE juga dapat digunakan sebagai indikator efisiensi teknis usaha (Budiasih dan Dewi, 2015).

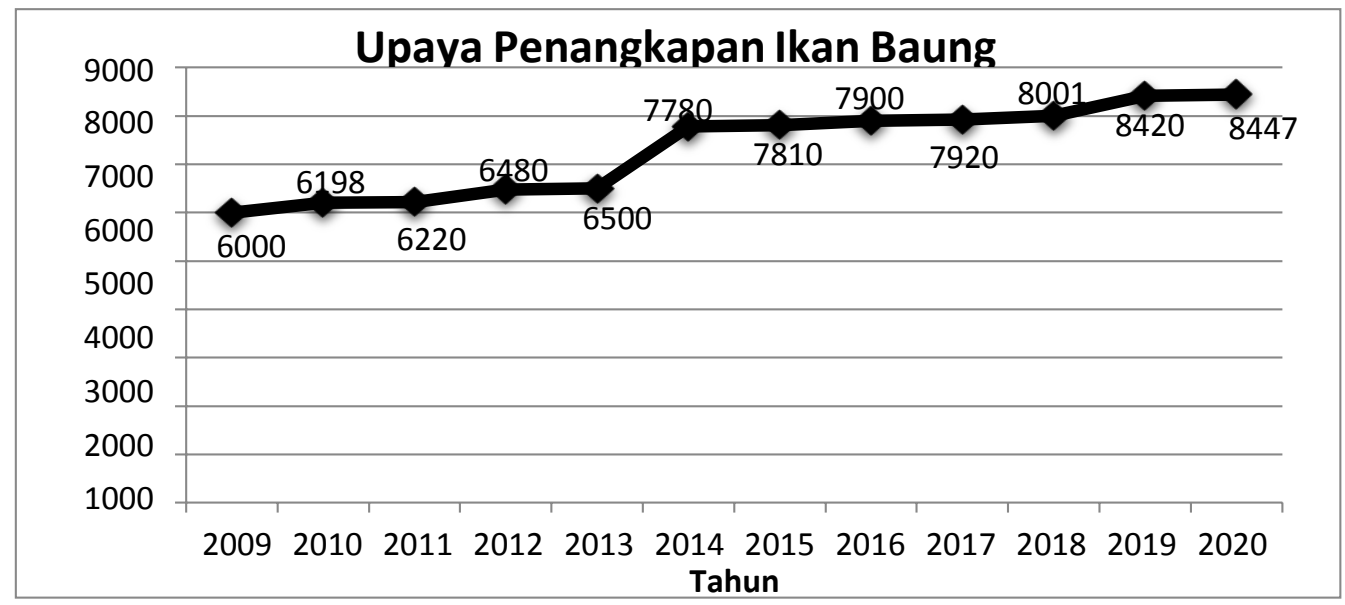

Gambar 1. Perkembangan Upaya Penangkapan Ikan Baung Tahun 2009-2020

\section{Hubungan CPUE dan effort}

Nilai CPUE digunakan untuk menentukan tren kinerja alat tangkap selama periode waktu tertentu. CPUE 
tergantung pada tingkat produksi dan tingkat upaya yang digunakan. Dari Gambar 2 diketahui bahwa hubungan antara CPUE dan effort ikan baung digambarkan dalam persamaan $\mathrm{y}=$ $0.0019 \mathrm{x}+0.0838$. Kondisi ini menunjukkan peningkatan aktivitas penangkapan (usaha) pada stok ikan baung akan menyebabkan penurunan produktivitas tangkapan (CPUE). Hubungan antara CPUE dan upaya penangkapan ikan baung ditunjukkan pada Gambar 2.

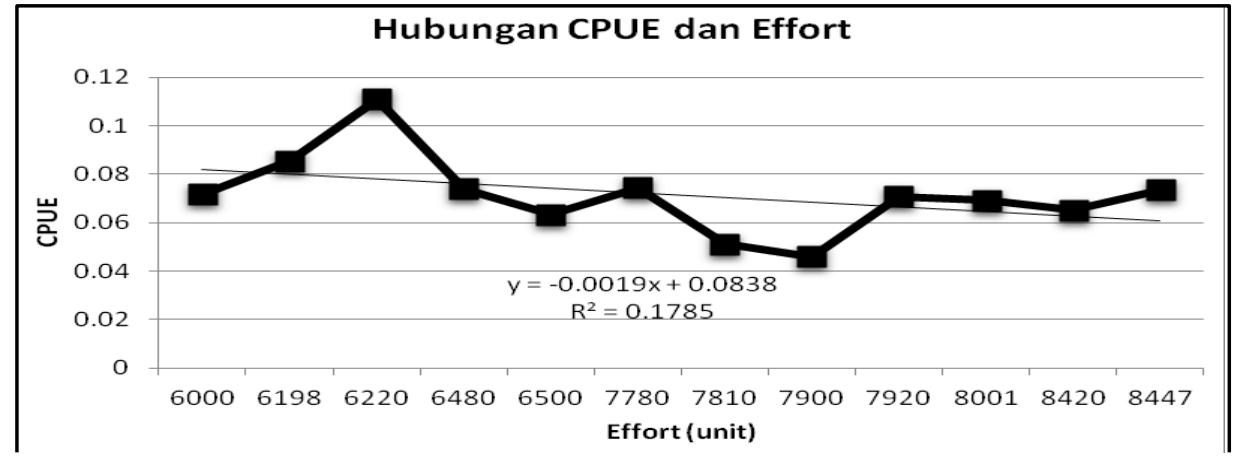

Gambar 2. Grafik Hubungan antara CPUE dengan Effort

\section{Estimasi Parameter Biologi}

Pendugaan parameter biologi dilakukan dengan menggunakan surplus produksi Schaefer, modal estimasi algoritma fox, CYP, Walter dan Hilborn (WH) dan Schnute. Parameter yang diestimasi meliputi

laju pertumbuhan intrinsik (r), kapasitas lingkungan perairan (K), koefisien daya tangkap (q). Perbandingan kelima model tersebut pada sumber daya ikan baung disajikan pada Tabel 2.

Tabel 2. Hasil Estimasi Parameter Biologi Ikan Baung

\begin{tabular}{cccc}
\hline \multirow{2}{*}{$\begin{array}{c}\text { Model Surplus } \\
\text { Produksi }\end{array}$} & \multicolumn{3}{c}{ Parameter Biologi } \\
\cline { 2 - 4 } (ton/tahun) & q (ton/unit) & K(ton/tahun) \\
\hline Schnute & 1,063724429 & 0,0000046 & 231.302 \\
Algoritma Fox & 0,102546534 & 0,0000065 & -277.249 \\
Walter Hilborn & 1,663690463 & $-0,000147297$ & 1.105 \\
CYP & 1,602345933 & $-0,000231774$ & -865 \\
Schaefer & 0,000158283 & 0,000000010 & 64.051 .255 \\
\hline
\end{tabular}

Sumber: Hasil analisis data, 2021

Berdasarkan perbandingan hasil regresi yang disajikan pada Tabel 3 . Artinya, nilai $\mathrm{R}^{2}$ tertinggi ditemukan pada model Schnute. Hal ini menunjukkan bahwa model Schnute merupakan model yang paling tepat untuk diterapkan pada ikan baung di perairan kabupaten Kampar 
Tabel 3. Hasil Regresi Model Surplus Produksi

\begin{tabular}{lcccc}
\hline \multirow{2}{*}{ Model } & \multicolumn{4}{c}{ Uji Regresi } \\
\cline { 2 - 5 } \multicolumn{1}{c}{ Uji $\boldsymbol{F}$} & Sig $\boldsymbol{F}$ & $\mathbf{R}^{\mathbf{2}}$ & Adj R $^{\mathbf{2}}$ \\
\hline Schnute & 224,0601142 & 0,000000095 & 0,982460765 & 0,978075956 \\
Algoritma Fox & 3,101563745 & 0,10870523 & 0,236732333 & 0,160405566 \\
Walter Hilborn & 2,384886716 & 0,154965352 & 0,505463224 & 0,293518891 \\
CYP & 1,7637452 & 0,231964151 & 0,306006796 & 0,132508495 \\
Schaefer & 2,295696943 & 0,15645999 & 0,337816263 & 0,190664321 \\
\hline
\end{tabular}

Sumber : Hasil Analisis Data, 2021

\section{Estimasi Parameter Ekonomi}

Parameter ekonomi yang dikaji dalam analisis bioekonomi berupa biaya dan harga yang dianggap konstan. Estimasi harga ikan Baung diperoleh dari harga nominal per ton per tahun yang disesuaikan dengan IHK yang berlaku di Kota Pekanbaru dengan tahun dasar 2018 (BPS Provinsi Riau, 2021). Setelah dianalisis, maka rata-rata harga riil yang diperoleh sebesar
Rp39.760.053/tahun dan rata-rata biaya riil sebesar Rp788.442/tahun.

\section{Analisis Bioekonomi Ikan Baung}

Pada analisis ini, pengelolaan ikan baung dapat dilakukan pada tiga kondisi yaitu MSY, MEY dan OA dengan menggunakan data time series produksi dan effort selama 12 tahun (2009-2020) dan parameter yang dibutuhkan dalam menganalisis yaitu $r$, q, K, p dan c. Hasil perhitungan diolah menggunakan Microsoft excel 2007.

Tabel 4. Analisis Bioekonomi Ikan Baung

\begin{tabular}{lrrr}
\hline \multirow{2}{*}{ Parameter } & \multicolumn{3}{c}{ Rezim } \\
\cline { 2 - 4 } & \multicolumn{1}{c}{ MEY } & \multicolumn{1}{c}{ MSY } & \multicolumn{1}{c}{ OA } \\
\hline Hasil tangkapan (ton) & 61.489 & 61.510 & 4.544 \\
Tingkat upaya (unit) & 114.567 & 116.764 & 229.133 \\
TR & 2.444 .790 .196 .662 & 2.445 .656 .568 .170 & 180.658 .262 .368 \\
TC & 90.329 .131 .184 & 92.061 .874 .201 & 180.658 .262 .368 \\
Rente ekonomi (Rp) & 2.354 .461 .065 .478 & 2.353 .594 .693 .969 & 0 \\
\hline Sumber: Hasil analisis data, 2021 & & &
\end{tabular}

Berdasarkan Tabel 4, hasil tangkapan maksimum lestari dicapai pada titik keseimbangan MSY yaitu sebesar 61.510 ton per tahun dengan upaya sebesar 116.764 unit per tahun. Nilai tersebut merupakan tingkat produksi maksimum dalam pemanfaatan sumber daya ikan baung yang dapat dilakukan tanpa mengancam kelestarian sumber daya ikan. Pemanfaatan sumber daya ikan dengan keuntungan maksimum terjadi pada kondisi MEY yaitu sebesar Rp2.354.461.065.478 dengan produksi sebesar 61.489 ton per tahun dan upaya sebesar 114.567 unit per tahun. Keuntungan pada kondisi MEY memiliki nilai keuntungan yang lebih besar daripada keuntungan yang diperoleh pada kondisi MSY sebesar 
Rp2.353.594.693.969. Nilai tersebut merupakan nilai optimal secara ekonomi dan sosial.

\section{Tingkat Pemanfaatan Ikan Baung}

Tingkat pemanfaatan ikan baung yang diperoleh dengan pembagian antara hasil tangkapan tiap tahunnya per tangkapan maksimum lestari catch
(MSY) yang telah diperoleh kemudian dikalikan dengan $100 \%$. Nilai pemanfaatan dapat digunakan untuk mengetahui kondisi stok ikan di perairan Kampar apakah masih dapat dioptimalkan atau sudah melebihi produksi lestasi maksimum (overfishing). Tingkat pemanfaatan ikan baung disajikan pada Tabel 5 .

Tabel 5. Tingkat Pemanfaatan Ikan Baung

\begin{tabular}{ccc}
\hline Tahun & Catch Ikan Baung (ton/tahun) & Tingkat Pemanfaatan/ Tahun \\
\hline 2009 & 431 & $70 \%$ \\
2010 & 530 & $86 \%$ \\
2011 & 690 & $112 \%$ \\
2012 & 480 & $78 \%$ \\
2013 & 412 & $67 \%$ \\
2014 & 580 & $94 \%$ \\
2015 & 400 & $65 \%$ \\
2016 & 364 & $59 \%$ \\
2017 & 560,8 & $91 \%$ \\
2018 & 554,69 & $90 \%$ \\
2019 & 548,58 & $89 \%$ \\
2020 & 620,75 & $101 \%$ \\
\hline Rata-rata & & $84 \%$
\end{tabular}

Sumber: Hasil analisis data, 2021

Berdasarkan Tabel 5 diketahui bahwa tingkat pemanfaatan ikan baung di Kampar sebesar 84\%. Mengacu pada ketentuan FAO (1995) dalam Bintoro (2005) bahwa tingkat pemanfaatan sebesar $75 \%$ sampai $100 \%$ dari potensi sumber daya lestari berada pada status fully exploited yaitu stok sumber daya sudah tereksploitasi mendekati nilai MSY. Peningkatan jumlah upaya penangkapan sangat tidak dianjurkan walaupun jumlah tangkapan masih bisa meningkat karena akan mengganggu kelestarian sumber daya ikan.

\section{PENUTUP}

Hasil analisis bioekonomi sumber daya ikan baung di Kabupaten
Kampar dianalisis dengan menggunakan 5 model pendekatan yaitu model Schaefer, Algoritma Fox, CYP, Walter-Hilborn dan Schnute. Secara statistik, model Schnute memiliki nilai $\mathrm{R}^{2}$ terbesar dibanding keempat model lainnya sebesar 0,982460765. Hasil analisis bioekonomi ikan baung di Kabupaten Kampar menghasilkan produksi tertinggi sebesar 61.510 ton per tahun pada rezim pengelolaan MSY. Sedangkan rente ekonomi maksimum terdapat pada rezim pengelolaan MEY sebesar Rp2.354.461.065.478 per tahun. Saat ini tingkat pemanfaatan sumber daya ikan baung di Kabupaten Kampar sebesar $84 \%$ termasuk ke dalam status fully exploited. 


\section{DAFTAR PUSTAKA}

Arief, Hazmi. 2016. Analisis Bioekonomi (Maximum

Sustainable Yield dan Maximum Economic Yield) Multi Spesies Perikanan Laut di PPI Kota Dumai Provinsi Riau. Berkala Perikanan Terubuk, Vol 44. No.1, 111-122.

Bintoro, F. 2005. Pemanfaatan Berkelanjutan Sumberdaya Ikan Tembang (Sardinella fimbriata Valenciennes) di Selat Madura Jawa Timur. Disertasi. Sekolah Pascasarjana Institut Pertanian Bogor.

BPS Kabupaten Kampar. 2021. Kabupaten Kampar Dalam Angka 2021. Badan Pusat Statistik Kabupaten Kampar. Bangkinang.

Gulland, J.A. 1983. Fishing and Stock of Fish at Iceland. Mui. 'Agric. Fish Food, Invest. (Ser.2) 23(4): $52 \pm 70$.

Schaefer. 1957. Bioeconomic Modelling and Fisheries Management. John Wiley and Sons.Toronto. Canada. 291 p.

Schnute, J. 1977. Improved Estimates from the Schaefer Production Models : $\quad$ Theoretical Considerations : J. Fish. Res. Board Can. 34:583-663. 